\title{
Evaluation of Earthquake Mitigation Capacity of County Administrative Units in Gansu Province
}

\author{
Jin Chen Wen Li Wenkai Chen Suping Zhang \\ Lanzhou Institute of Seismology, CEA, Lanzhou 730000, China
}

\begin{abstract}
The paper established the evaluation index system of earthquake mitigation capacity of county administrative units in Gansu province. According to the goal, three guidelines, nine indicators and ten variables were set. The paper calculated the environment supporting capacity, facilities supporting capacity and resources supporting capacity of counties in Gansu province by determining the weight of each index factor based on the analytic hierarchy process (AHP). Then we got the evaluation figure of earthquake mitigation capacity of county administrative units in Gansu province. The result of research shows that the earthquake mitigation capacity of Anning district is the strongest, and that of Zhouqu county is the weakest. The earthquake mitigation capacity of the northwest and northeast of Gansu province is stronger overall, especially the Dunhuang-Akesai-Subei area, Jinchuan district and Xifeng district. The earthquake mitigation capacity of Tianzhu county and Gannan-Longnan area is weaker overall. The geographical environment has great influence on earthquake mitigation capacity. The earthquake mitigation capacity of area with violent tectonic activity and great topographic relief is always weaker. The province should strengthen the construction of infrastructure and resources to make up for the lack of environmental support.
\end{abstract}

\section{Keywords}

Gansu province; County administrative units; Earthquake mitigation capacity; Analytic hierarchy process (AHP)

\section{甘肃省县级行政单元防震减灾能力评价}

\author{
陈晋 李雯 陈文凯 张苏平 \\ 中国地震局兰州地震研究所, 甘肃 兰州 73000 , 中国
}

摘要: 本文建立了甘肃省县级行政单元防震减灾能力评价指标体系, 围绕着一个目标, 设定 了 3 个准则、9 个指标和 10 个变量。采用层次分析法确定各指标因子的权重, 对甘肃省各 县区应对地震灾害的环境支撑能力、设施支撑能力和资源支撑能力进行计算, 得到了甘肃省 县级行政单元防震减灾能力评估图。研究结果表明: 兰州市安宁区的防震减灾能力最强, 舟 曲县防震减灾能力在所有区县中最弱; 甘肃省西北部、东北部地区防震减灾能力整体较强, 其中敦煌-阿克塞-肃北地区、金川区、西峰区尤为突出; 天祝县、甘南-陇南地区防震减灾能 
力较弱; 地理环境对防震减灾能力的影响很大, 构造活动剧烈、地形起伏大的地区防震减灾 能力往往较弱; 全省应加强基础设施和基础资源的建设, 来弥补环境支撑能力的不足。

矢键词：甘肃省；县级行政单元；防震减灾能力；层次分析法

\section{0 引言}

甘肃省是我国地震活动频繁的少 数几个省份之一, 地震活动水平位居 我国前列，历史上发生过多次破坏性 地震，这些地震导致甘肃省遭受严重 的人员伤亡和经济损失 ${ }^{[1]}$ 。甘肃省内分 布有祁连山地震带、天水地震带、阿 尔金地震带等多条地震带，历史上的 多次破坏性地震也集中在这些断裂带 上, 如 1920 年海原 8.5 级地震、 1927 年古浪 8.0 级地震、1 1954 年山丹 7.25 级地震等。近几年甘肃省及周边地震

（2008 年汶川 8.0 级地震、2013 年岷 县漳县 6.6 级地震、 2015 年门源 6.4 级 地震、2017 年九寨沟 7.0 级地震) 发 生频率明显提高, 且随着地区经济的 快速发展, 地震灾害对我省社会经济 的影响将会越来越大 ${ }^{[2]}$ 。

防震减灾能力是一个区域面对地 震灾害时降低地震破坏和损失的能 力。防震减灾能力越高, 表明地震对 当地社会经济发展造成的危害越小。 20 世纪 90 年代, 世界各国相继对防震 减灾展开科学研究, 建立了各种地震 减灾能力评价指标体系 ${ }^{[3-7]}$, 国外最具 代表性的成果是地震灾害风险指数

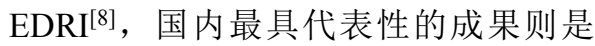
由谢礼立院士所提出的基于三准则对 城市防震减灾能力进行评价的体系 ${ }^{[9]}$ 。 本文针对甘肃省, 建立基于县级行政 单元的防震减灾能力评估指标体系, 对甘肃省各区县的防震减灾能力进行 评估, 从而为正确认识甘肃省各区县
防震减灾能力分布特征, 实现防震减 灾资源科学配置提供科学的依据。

\section{1 数据和方法}

\section{1 数据来源与处理}

评估指标的准确性直接影响评估 结果的可靠性。因此本文采用国家权 威机构发布的统计数据进行计算分 析。人口、经济、医疗卫生、财政储 蓄、交通通讯等数据来源于 2016 年甘 肃省统计年鉴（统计数据截止日期为 2015 年 12 月）和中国县域统计年鉴 2016 (县市卷) ; 地形数据来源于日 本 ASTER 卫星提供的 DEM 数据（空 间分辨率 $30 \mathrm{~m}$ ）; 行政区划、活动断 层数据来源于甘肃省地震应急基础数 据库。本文中各指标的空间化处理是 在 ArcGIS 软件平台中完成的, 坐标系 统采用WGS-1984。

\section{2 分析方法}

本文所采用的分析方法为层次分 析法 ( AHP , analytic hierarchy process），它是 Saaty[10]等人在 20 世 纪 70 年代初提出的一种多准则决策方 法。决策过程将各因子进行分类, 形 成层次化的分析模型, 之后对各层元 素之间两两对比, 确立判别矩阵, 再 经过一致性判断, 最终确定各因子的 重要性权重, 从而为分析和预测事物 的发展提供可比较的定量依据。文中 对统计数据进行处理时所采用的方法 为无量纲化中的直线型无量纲化方 法, 来消除各指标量纲对结果的影 响。 
表 1 甘肃省县级行政单元防震减灾能力评估指标体系

Table 1 The evaluation index system of earthquake mitigation capacity of county administrative units in Gansu

\begin{tabular}{cccc} 
& \multicolumn{3}{c}{ province } \\
\hline 目标层 & 准则层 & 指标层 & 因子层 \\
\hline & 环境支撑能力 & 地形起伏 $(0.178)$ & 地形起伏度 $(0.178)$ \\
& $(0.547)$ & 活动断层 $(0.369)$ & 活动断层分布 $(0.369)$ \\
\cline { 2 - 4 } & 设施支撑能力 & 建筑物质量 $(0.188)$ & 建筑物抗震能力 $(0.188)$ \\
& $(0.345)$ & 交通条件 $(0.080)$ & 公路密度 $\left(/ \mathrm{km}^{2}\right)(0.080)$ \\
& 医疗条件 $(0.047)$ & 医疗床位 $(/$ 万人 $)(0.047)$ \\
防震减 & 通讯条件 $(0.029)$ & 电话密度 $\left(/ \mathrm{km}^{2}\right)(0.029)$ \\
\cline { 2 - 4 } 能力 & 劳力资源 $(0.022)$ & 男性青壮年人数 $\left(/ \mathrm{km}^{2}\right)$ \\
& & & $(0.022)$ \\
& 资源支撑能力 & & 财政收入密度 $\left(/ \mathrm{km}^{2}\right)$ \\
& $(0.108)$ & 财力资源 $(0.074)$ & $(0.037)$ \\
& & & 居民人均储蓄 $(0.037)$ \\
& & 认知水平 $(0.013)$ & 高中以上人口密度 $\left(/ \mathrm{km}^{2}\right)$ \\
& & & $(0.013)$ \\
\hline
\end{tabular}

\section{2 防震减灾能力评估}

\section{1 防震减灾能力评价指标体系}

本文从环境支撑能力、设施支撑 能力和资源支撑能力三个方面分别选 取评估指标与因子，构建甘肃省县级 行政单元防震减灾能力评估指标体 系。环境支撑能力包括地形起伏和活 动断层的分布, 在地形起伏大的地方 开展救灾抢险工作的难度较大, 活动 断层分布较多的地区其发生地震灾害 的几率也相对较高。设施支撑能力包 括建筑物质量、交通条件、医疗条件 以及通讯条件, 其中建筑物质量与当 地经济、人民的生活生产水平息息相 关, 当地经济和人民生活水平越高, 居住的建筑物整体质量水平往往也越 高。资源支撑能力包括劳力资源、财 力资源以及认知水平, 地震发生后当 地能调动用于救援的人力财力越多, 救灾的效果会越好。另外，当地居民 的知识水平也对防震减灾政策执行的 难易造成一定影响。评估指标权重通 过层次分析法确定, 根据各个指标的 相对重要性, 对各层次上的要素采用 两两比较的方法建立判断矩阵, 并对 每个判断矩阵进行一致性检验。经检
验, 各判断矩阵的随机一致性比率均 低于 0.1 , 即认为判断矩阵具有满意的 一致性。如表 1 (从上往下), 准则层 上计算的各准则权重分别为 $(0.547$, $0.345,0.108$ ）；指标层上计算的各指 标权重分别为 $(0.178,0.369,0.188$, $0.080,0.047,0.029,0.022,0.074$, 0.013 )。

\section{2 结果与分析}

\section{（1）环境支撑能力}

综合地形起伏度和活动断层两个 因素, 计算得到甘肃省各县区环境支 撑能力图, 从图中可以看出环境支撑 能力强的地区主要分布在敦煌-瓜州、 金昌-民勤、定西-平凉-庆阳以及兰州 市区这四个区域。这些区域的地形起 伏度比较低, 其中敦煌-瓜州、金昌-民 勤和兰州市区地势较为平坦。环境支 撑能力弱的区域主要分布在甘南-陇南 一带以及肃南-天祝一带, 肃南-天祝一 带属于祁连山脉边缘, 地势起伏较 大, 甘南-陇南地区处于省内主要活断 层东昆仑断裂带上。 


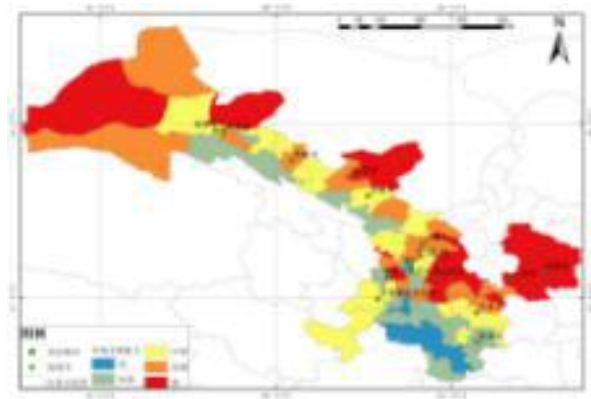

图 1 甘肃省各区县环境支撑能力分布图 Figure 1 The distribution of environmental support capacity of various districts and counties in Gansu province

\section{(2) 设施支撑能力}

综合建筑物质量、交通条件、医 疗条件、通讯条件, 计算得到甘肃省 各区县设施支撑能力分布图。如图, 设施支撑能力强的地区主要为阿克塞肃北-肃南、金昌市区、白银市区以及 兰州市区。其中阿克塞-肃北-肃南地区 地广人稀, 矿产资源丰富, 人均 GDP 在省内均位于前列, 房屋质量整体较 好。甘肃中部地区以及东南部地区人 口分布密集, 人均 GDP 被拉低, 基础 设施支撑能力无法满足过多人口的需 求。

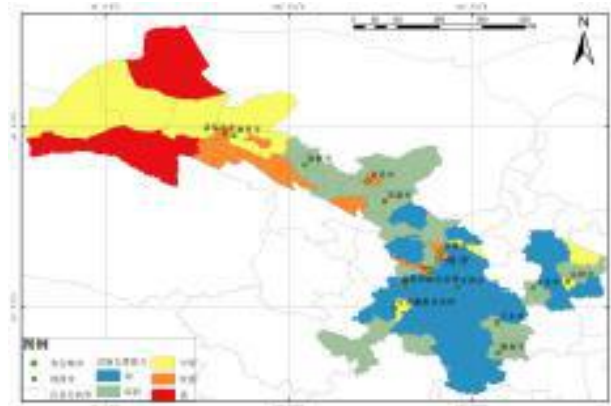

图 2 甘肃省各区县设施支撑能力分布图

Figure 2 The distribution of facilities supporting capacity of various districts and counties in Gansu province

\section{（3）资源支撑能力}

通过劳力资源、财力资源以及认 知水平三要素计算得到甘肃省各区县 资源支撑能力分布图。如图, 甘肃省 资源支撑能力整体较弱, 其中兰州市 安宁区资源支撑能力最强, 其余支撑 能力较强的区域基本上都为各市的市 区。这种现象出现是由于甘肃省整体 的经济发展落后, 政府财政收入和居 民人均储蓄都较少, 此外, 全省教育 水平落后, 以致人民认知水平较低。

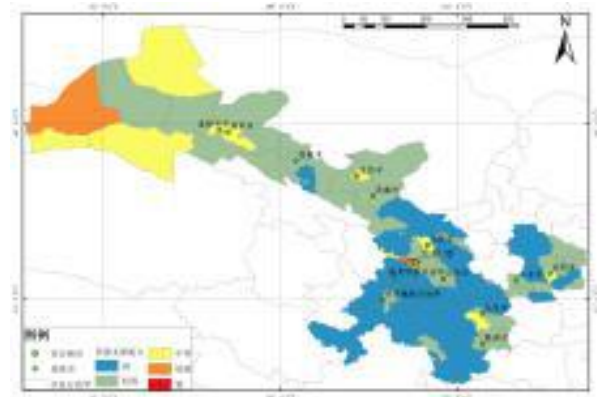

图 3 甘肃省各区县资源支撑能力分布图 Figure 3 The distribution of resources supporting capacity of various districts and counties in Gansu province

\section{（4）防震减灾能力}

综合环境支撑能力、设施支撑能 力和资源支撑能力, 最终计算得到甘 肃省各区县防震减灾能力分布图。如 图, 兰州市安宁区的防震减灾能力最 强, 甘肃省西北部、东北部地区防震 减灾能力整体较强, 其中敦煌-阿克塞肃北地区、金川区、西峰区尤为突 出。天祝县、甘南-陇南地区防震减灾 能力较弱, 舟曲县防震减灾能力在所 有区县中最弱。 


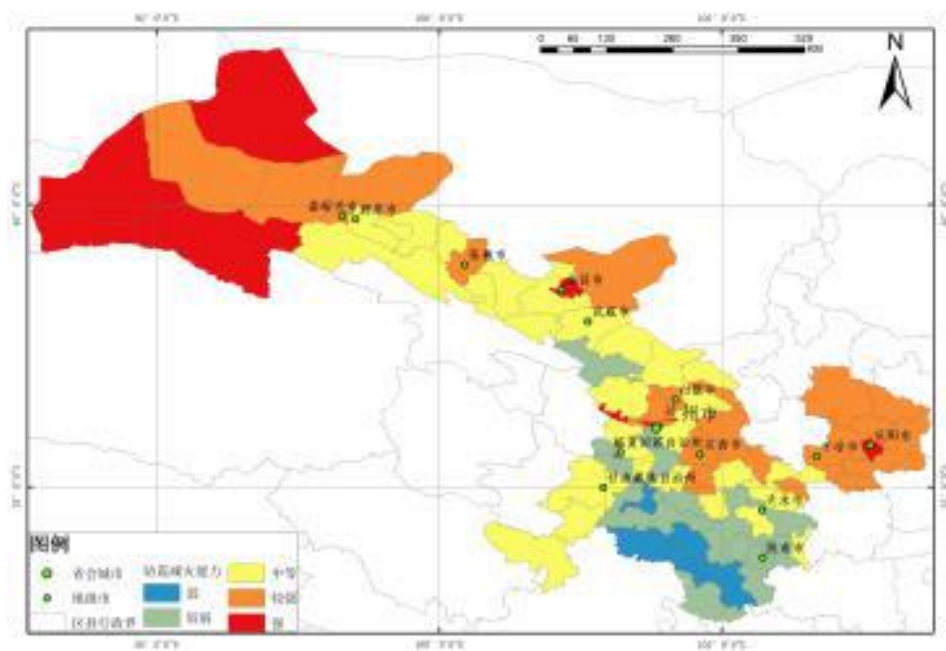

图 4 甘肃省各区县防震减灾能力分布图

Figure 3 The distribution of earthquake mitigation capacity of various districts and counties in Gansu province

\section{3 结论}

本文建立了甘肃省县级行政单元 防震减灾能力评估指标体系, 采用层 次分析法确定各指标因子权重，在 ArcGIS 软件平台下对甘肃省各区县环 境支撑能力、设施支撑能力、资源支 撑能力进行计算, 在此基础上得到了 甘肃省防震减灾能力评估图。研究结 果表明: 兰州市安宁区的防震减灾能 力最强, 舟曲县防震减灾能力在所有 区县中最弱; 甘肃省西北部、东北部 地区防震减灾能力整体较强, 其中敦 煌-阿克塞-肃北地区、金川区、西峰区 尤为突出; 天祝县、甘南-陇南地区防 震减灾能力较弱; 地理环境对防震减 灾能力的影响很大, 构造活动剧烈、 地形起伏大的地区防震减灾能力往往 较弱; 全省应加强基础设施和基础资 源的建设, 来弥补环境支撑能力的不 足。

\section{致谢}

基金项目: 甘肃省科技支撑项目 （1504FKCA065）、中国地震局地震 预测研究所基本科研业务专项
（2015IESLZ06）、国家重点研发计划 （2017YFB0504104）共同资助。

\section{参考文献}

[1] 裴惠娟, 周中红, 孙艳萍等. 甘 肃省地震灾害时空分布特征研究 [J]. 自然灾害学报, 2015, 24(3): 67-75.

[2] 聂高众, 高建国, 马宗晋等. 中 国未来 10-15 年地震灾害的风险 评估 $[\mathrm{J}]$. 自然灾害学报, 2002, 11(1): 68-73.

[3] 刘晓静,薄涛,郭燕.我国地震综合减 灾能力评价指标体系—以唐山 市为例 [J].自然灾害学报,2012,(06): 043- 49.

[4] 郭燕,薄涛,刘晓静.防震减灾能力评 估方法及其在汶川地震中的应用 [J].自然灾害学报,2013,(05):03643.

[5] 邓砚，苏桂武，仵焕杰.中国区域 防震减灾能力的综合评估 $[\mathrm{J}]$.地震 地质，2013，35（3）: 584-592.

[6] 刘莉, 谢礼立.层次分析法在城市 防震减灾能力评估中的应用 $[\mathrm{J}]$. 自 然灾害学报，2008,17（2）：48- 
52.

[7] 李智, 赵晓辉, 曲乐.区域防震减 灾能力评估方法研究 [J].防灾减灾 学报, 2011, 27 (3) : 1-6.

[8] 何玉林, 韩渭宾, 裴锡瑜, 等.城 市地区防御地震灾害风险评估项 目总数 $[\mathrm{J}]$.四川地震, 2002

(4) : 35-38.

[9] 刘莉, 谢礼立.关于城市防震减灾 能力影响因素的探讨 [J].世界地震 工程, 2008,24 (1) : 88-92.

[10] Saaty TL. The Analytic Hierarchy Process[M]. New York McGrawHill, 1980. 